\title{
Aging male's strength reduction: population based study
}

http://dx.doi.org/10.11606/1807-5509201800010059

\author{
Leandro Quadro CORRÊA* \\ Marcelo Cozzensa da SILVA** \\ Marlos Rodrigues DOMINGUES** \\ Airton José ROMBALDI** \\ * Universidade \\ Federal do Rio \\ Grande, Rio Grande, \\ RS, Brasil. \\ ** Universidade \\ Federal de Pelotas, \\ Pelotas, RS, Brasil.
}

\begin{abstract}
We conducted a population-based cross-sectional study to identify the prevalence of aging male's strength reduction (AMSR) and factors associated to this condition. The study included 421 men aged 40 years or older, living in the urban area of Pelotas, Southern Brazil. The questionnaire covered sociodemographic, behavioral and health variables and, to assess the aging male's strength reduction, one question of the Aging Male's Symptoms Scale was used. The prevalence of AMSR was 19.0\% $\left(\mathrm{Cl}_{95 \%} 15.2-22.8\right)$. After controlling for confounders, the AMSR was significantly associated with aging, smoking, physical activity score and self-perceived health status. Our findings reinforce the need to keep healthy behaviors such as not smoking and to practice regular physical activity as a healthier lifestyle to reduce the AMSR acceleration and increase life quality and expectancy.
\end{abstract}

KeYwords: Aging; Males; Strength; Epidemiology; Urban Population.

\section{Introduction}

Aging is distinctive and individually variable within one species or among different species. However, many definitions for the biologic process of aging point out the progressive losses in functionality and the increased likelihood to be more susceptible to many diseases, increasing death risk ${ }^{1,2}$.

The male's aging is characterized by symptoms that mimic androgenic deficiency in young adults such as decrease in muscle mass and strength, abdominal fat increase - especially visceral fat along with insulin resistance and atherogenic dyslipidemias, low libido and loss of body hair, osteopenia, cognitive impairments, depression, insomnia, sudoresis and lower overall well being?

\section{Methods}

A cross-sectional population-based study was conducted in the urban area of Pelotas (Brazil) during 2008. The city is located in Southern Brazil and has around 340 thousand inhabitants. Nearly $32 \%$ of population is aged 40 or older
The decrease in muscle mass and strength are linked to the aging process ${ }^{4}$ and result in a higher chance of falling and consequently bone fractures that hinder quality of life and health in the elderly.

Aging leads to a decrease in strength and muscle power ${ }^{5}$. Moreover muscle strength reductions is a critical component in maintaining physical function, mobility, and vitality in older ages being consistently reported as an independent risk factors for high mortality in this population ${ }^{6}$.

Thus, this study was carried out to measure the prevalence of self-perceived muscular strength loss and associated factors in a representative sample of men aged 40 or older living in the urban area of Pelotas, Brazil.

(http://www.ibge.gov.br) ${ }^{7}$. The Brazilian Institute of Geography and Statistics (IBGE) delimits the city in 408 census tracts. From the 404 tracts with households, 45 were randomly sampled for the study. Within each census tracts a starting point 
was chosen and 20 households were systematically selected. A total of 900 households where sampled and all men aged 40 or older were considered eligible for the study. We excluded from the sample institutionalized individuals (shelters, hospitals, prisons and headquarters), those with severely disabled (tetraplegic, cerebral palsy, etc.) and people unable to respond/understand the questionnaire.

The outcome - prevalence of self-perceived muscular strength loss - was based on the question: "have you noticed any decrease in your muscular strength? (feeling weakness)". The question was taken from the aging male's symptoms scale (AMS), validated by Heinemann et al. ${ }^{8}$ and previously used in Brazil in a population-based study by CORRÊA et al. ${ }^{9}$. The following sentences were read to the interviewees: "I haven't notice any decrease in muscular strength"; "I noticed a mild decrease in muscular strength"; "Inoticed a moderate decrease in muscular strength"; I noticed a severe decrease in muscular strength"; "I noticed an extremely severe decrease in muscular strength". Nevertheless, we considered positive for the outcome men reporting moderate, severe or extremely severe decreases in muscular strength.

Demographic, health and socioeconomic information were assessed by a pre-tested questionnaire The independent variables were age; skin color (categorized as white or nonwhite, according to the interviewer's observation); marital status (with or without partner); economic level - according to the Brazilian Association of Market Research Agencies (A - wealthiest; B; C; $\mathrm{D} / \mathrm{E})^{10}$; schooling (complete years of education); smoking (current smoker; former smoker; never smoked); and self-perceived health (excellent; very good; good; fair; poor). The nutritional status was based on self-reported height and weight (body mass index $-\mathrm{BMI}$ ), according to the $\mathrm{WHO}$ criteria $^{11}$. To measure physical activity, we used the International Physical Activity Questionnaire (IPAQ) ${ }^{12}$. We considered as physically active men attaining at least 150 minutes per week of physical activities, according to the recommended by $\mathrm{ACSM}^{13}$.

The questionnaire was administered by face-toface individual interviews. Interviewers were men and women with at least high school education trained for 40 hours. The staff was unaware of the goals of the study. Data collection supervisors randomly re-interview $10 \%$ of the sample with a shorter version of the questionnaire to measure concordance and for quality control purposes. The questionnaire was tested during a pilot-study carried out within a census tract not sampled for the study.

Data was double entered in EpiInfo 6. Data analysis was done with Stata 9.0. First, a descriptive analysis of the decrease in muscular strength according to socioeconomic, nutritional and demographic variables was made. During crude analysis, we used chi-square tests to measure the association between the outcome and independent variables. The multivariable analysis, by Poisson regression with robust variance, followed a fourlevel hierarchical model. The distal level included age and skin color; the second level included schooling, economic level, and marital status; third level - BMI, smoking, and physical activity; and the self-perceived health status and muscular strength loss were included in the last level. The effects of the variables were controlled for the same level and upper level covariates. We retained in the model those presenting p-values below 0.2 and the significance level was set to $5 \%$.

The study was approved by the Ethics and Research Committee of the Physical Education School of the Federal University of Pelotas (protocol number 005/2008) and data were collected after completion of the informed consent form.

\section{Results}

We included 421 men (aged 40 years or older) from 876 households and the non-respondent rate was $8.3 \%$. The mean age of the sample was $54.5( \pm 10.5$ years) and $29.9 \%$ studied up to 4 years. Most men (85\%) were white and nearly half (46.2\%) belonged to socioeconomic level C; $77.2 \%$ were married or were living with a partner. We observed that $20 \%$ were current smokers, $67.1 \%$ were considered obese/ overweight and $37.2 \%$ were physically inactive or insufficiently active (TABLE 1). The median time spent on physical activities was 223 minutes/week, ranging from 0 to 8650 minutes. 
TABLE 1 - Sample characteristics according to independent variables. Pelotas - Brazil, 2008.

\begin{tabular}{|c|c|c|}
\hline Variables & $\mathbf{N}$ & $\%$ \\
\hline \multicolumn{3}{|l|}{ Age } \\
\hline $40-49$ & 164 & 39.0 \\
\hline $50-59$ & 137 & 32.5 \\
\hline $60-69$ & 77 & 18.3 \\
\hline 70 or more & 43 & 10.2 \\
\hline \multicolumn{3}{|l|}{ Skin color } \\
\hline White & 357 & 85.2 \\
\hline Black/Mixed & 62 & 14.8 \\
\hline \multicolumn{3}{|l|}{ Education (years) } \\
\hline 0 & 14 & 3.3 \\
\hline 1 to 4 & 112 & 26.6 \\
\hline 5 to 8 & 146 & 34.7 \\
\hline 9 to 11 & 76 & 18.1 \\
\hline 12 or more & 73 & 17.3 \\
\hline \multicolumn{3}{|l|}{ Socioeconomic level } \\
\hline A (Highest) & 33 & 8.0 \\
\hline $\mathrm{B}$ & 140 & 33.9 \\
\hline $\mathrm{C}$ & 191 & 46.2 \\
\hline $\mathrm{D} / \mathrm{E}$ & 49 & 11.9 \\
\hline \multicolumn{3}{|l|}{ Marital status } \\
\hline Married or living with partner & 335 & 77.2 \\
\hline Living alone & 96 & 22.8 \\
\hline \multicolumn{3}{|l|}{ BMI } \\
\hline Normal & 133 & 32.9 \\
\hline Overweight & 183 & 45.3 \\
\hline Obese & 88 & 21.8 \\
\hline \multicolumn{3}{|l|}{ Smoking } \\
\hline Never smoked & 128 & 30.4 \\
\hline Former smoker & 175 & 41.6 \\
\hline Smoker & 118 & 28.0 \\
\hline \multicolumn{3}{|l|}{ Physical activity score } \\
\hline $0 \mathrm{~min} / \mathrm{wk}$ & 30 & 7.2 \\
\hline 10 to $149 \mathrm{~min} / \mathrm{wk}$ & 125 & 30.0 \\
\hline 150 to $499 \mathrm{~min} / \mathrm{wk}$ & 123 & 29.5 \\
\hline 500 or more $\mathrm{min} / \mathrm{wk}$ & 139 & 33.3 \\
\hline \multicolumn{3}{|l|}{ Self-perceived health } \\
\hline Excellent & 41 & 9.8 \\
\hline Very good & 58 & 13.8 \\
\hline Good & 216 & 51.4 \\
\hline Fair & 85 & 20.2 \\
\hline Poor & 20 & 4.8 \\
\hline
\end{tabular}

With respect to the self-perceived muscular strength, 19\% (CI 95\%: 15.2\%-22.8\%) of men reported decrease in muscular strength. During crude analysis (TABLE 2), we observed that selfperceived muscular strength was directly associated to older ages and worse health perception; and inversely associated to lower physical activity. Former or current smokers presented a twofold increase in self-perceived muscular strength decrease compared to men that never smoked. 
TABLE 2 - Prevalence of decreased strength and crude analysis of decrease in strength and independent variables studied.

\begin{tabular}{|c|c|c|c|c|}
\hline \multirow{2}{*}{ Variables } & \multirow[b]{2}{*}{$\mathbf{N}$} & \multirow[b]{2}{*}{$\%$} & \multicolumn{2}{|c|}{ Crude analysis } \\
\hline & & & PR (95\%CI) & P-value \\
\hline$\overline{\text { Age }}$ & & & & $<0.001^{* *}$ \\
\hline $40-49$ & 15 & 9.3 & 1.0 & \\
\hline $50-59$ & 23 & 17.2 & $1.8(1.0$ to 3.5$)$ & \\
\hline $60-69$ & 21 & 27.3 & $2.9(1.6$ to 5.4$)$ & \\
\hline 70 or more & 20 & 46.5 & $5.0(2.8$ to 9.0$)$ & \\
\hline Skin color & & & & $0.5^{*}$ \\
\hline White & 68 & 19.3 & 1.0 & \\
\hline Black/Mixed & 10 & 16.9 & $0.8(0.5$ to 1.4$)$ & \\
\hline Education (years) & & & & $0.07^{* *}$ \\
\hline 0 & 7 & 50.0 & 1.0 & \\
\hline 1 to 4 & 25 & 22.5 & $0.4(0.3$ to 0.8$)$ & \\
\hline 5 to 8 & 23 & 15.9 & $0.3(0.2$ to 0.6$)$ & \\
\hline 9 to 11 & 15 & 20.0 & $0.4(0.2$ to 0.9$)$ & \\
\hline 12 or more & 9 & 12.9 & $0.3(0.1$ to 0.7$)$ & \\
\hline Socioeconomic level & & & & $0.1^{* *}$ \\
\hline A (Highest) & 6 & 18.7 & 1.0 & \\
\hline $\mathrm{B}$ & 19 & 13.9 & $0.7(0.2$ to 2.4$)$ & \\
\hline $\mathrm{C}$ & 38 & 19.9 & $1.1(0.3$ to 3.2$)$ & \\
\hline $\mathrm{D} / \mathrm{E}$ & 14 & 29.8 & $1.6(0.5$ to 4.9$)$ & \\
\hline Marital status & & & & $0.6^{*}$ \\
\hline Married or living with partner & 59 & 18.4 & 1.0 & \\
\hline Living alone & 20 & 21.3 & $1.2(0.6$ to 2.1$)$ & \\
\hline BMI & & & & $0.7^{* *}$ \\
\hline Normal & 28 & 21.4 & 1.0 & \\
\hline Overweight & 28 & 15.6 & $0.7(0.5$ to 1.1$)$ & \\
\hline Obese & 18 & 20.5 & $0.9(0.5$ to 1.7$)$ & \\
\hline Smoking & & & & $0.02^{*}$ \\
\hline Never smoked & 13 & 10.4 & 1.0 & \\
\hline Former smoker & 41 & 23.8 & $2.2(1.3$ to 4.0$)$ & \\
\hline Smoker & 25 & 21.2 & $2.0(1.1$ to 3.9$)$ & \\
\hline Physical activity score & & & & $<0.001^{* *}$ \\
\hline $0 \mathrm{~min} / \mathrm{wk}$ & 12 & 40.0 & 1.0 & \\
\hline 10 to $149 \mathrm{~min} / \mathrm{wk}$ & 30 & 24.4 & $0.6(0.3$ to 1.1$)$ & \\
\hline 150 to $499 \mathrm{~min} / \mathrm{wk}$ & 20 & 16.7 & $0.4(0.2$ to 0.8$)$ & \\
\hline 500 or more $\mathrm{min} / \mathrm{wk}$ & 16 & 11.5 & $0.3(0.1$ to 0.6$)$ & \\
\hline Self-perceived health & & & & $<0.001^{* *}$ \\
\hline Excellent & 6 & 15.0 & 1.0 & \\
\hline Very good & 7 & 12.3 & $0.8(0.2$ to 3.1$)$ & \\
\hline Good & 26 & 12.2 & $0.8(0.4$ to 1.8$)$ & \\
\hline Fair & 27 & 32.1 & $1.4(1.0$ to 4.5$)$ & \\
\hline Poor & 13 & 65.0 & $4.3(2.1$ to 8.8$)$ & \\
\hline
\end{tabular}

After adjusting for confounders (age, skin color, educational level, socioeconomic status, marital status, body mass index, smoking, physical activity score and self perceived health) (TABLE 3), age, smoking, physical activity and self-perceived health remained associated to the outcome. 
TABLE 3 - Multivariable analysis of the association between decreased strength and independent variables studied.

\begin{tabular}{lcc}
\hline \multirow{2}{*}{ Variables } & \multicolumn{2}{c}{ Adjusted analysis } \\
\cline { 2 - 3 } Age & PR (95\% $\mathbf{C I})$ & P-value \\
$\quad 40-49$ & 1.0 & \\
$50-59$ & $2.1(1.2$ to 4.1$)$ & \\
$60-69$ & $3.1(1.7$ to 5.6$)$ & \\
70 or more & $4.1(2.2$ to 7.8$)$ & \\
\hline Smoking & & \\
Never smoked & 1.0 & \\
Former smoker & $1.6(0.9$ to 2.9$)$ & \\
Smoker & $2.4(1.3$ to 4.5$)$ & \\
\hline Physical activity score & & \\
0 min/wk & 1.0 & \\
10 to 149 min/wk & $0.7(0.4$ to 1.1$)$ & \\
150 to 499 min/wk & $0.6(0.3$ to 1.0$)$ & \\
500 or more min/wk & $0.4(0.2$ to 0.8$)$ & \\
\hline Self-perceived health & & \\
Excellent & 1.0 & \\
Very good & $0.8(0.2$ to 3.1$)$ & \\
Good & $0.8(0.3$ to 2.1$)$ & \\
Fair & $1.8(0.8$ to 4.3$)$ & \\
Poor & $2.3(1.0$ to 5.4$)$ & \\
\hline
\end{tabular}

The prevalence of self-perceived muscular strength loss was increasing linearly with age; the oldest age group (70 or older) presented the highest risk, nearly fourfold increase compared to the 40-49 years age group. Current smokers presented a nearly 2.5-fold increase compared to men who never smoked. As the mean time spent with physical activities increased, the protection against strength loss increased as well (FIGURE 1). Men presenting physical activity scores above 500 minutes/week were $60 \%$ less likely to report self-perceived muscular strength loss compared to inactive men (physical activity score 0 ). With respect to selfperceived health, a linear increase in the report of muscular strength loss, men perceiving their own health as poor were 2.3 times more likely to report aging symptoms compared to men perceiving their health as excellent (TABLE 3).

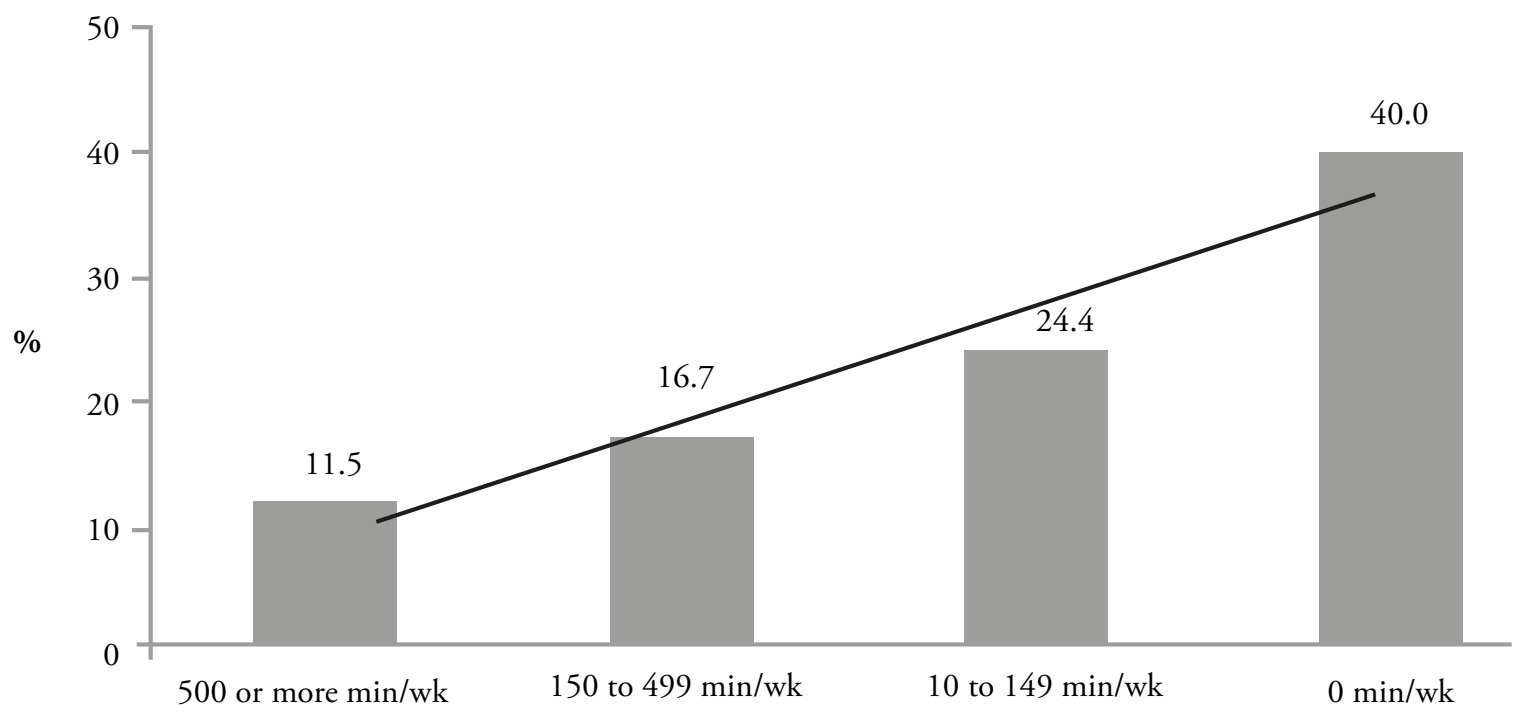

FIGURE 1 - Prevalence of self-reported muscular strength loss according to the physical activity score. 


\section{Discussion}

We studied a representative sample of of men aged 40 years or older from Pelotas (Brazil), with low refuse rate $(8.3 \%)$. Sociodemographics were in agreement with census data for this city (http:// www.ibge.gov.br) ${ }^{7}$.

The self-perceived muscular strength loss was assessed by one question from the AMS scale. The scale was originally suggested by HaINEMANN et al. ${ }^{8}$ and is validated in 14 languages ${ }^{14}$, including Portuguese, and is used by the Society for the Study of Androgen Deficiency - The Andropause Society (http://www.andropause.org.uk/) ${ }^{15}$ to identify men's aging symptoms and to establish if they need hormonal therapy. The scale was developed to be self-administered but was adapted to face-to-face interviews in an attempt to help administering and understanding by men in population surveys.

In our study, the frequency of self-perceived muscular strength loss increased with age, nearly half of men older than 70 reported strength loss. The study by CarvalHo and Soares ${ }^{16}$, showed that between the ages of 50 and 70 a $15 \%$ decrease in muscular strength is observed, and, after that period, the decrease is nearly to $30 \%$ per decade. Frontera et al. $^{17}$, in a 12 -year follow-up study, observed decrease in strength of the lower limbs ranging from 1.4 to $2.5 \%$ a year, and the best predictor of such decrease was loss of muscular mass.

We observed that men that never smoked were less likely to perceive decrease in muscular strength. Rom et al. $(2013)^{18}$ report that smokers have molecular responses that lead to muscle atrophy resulting in reduced muscle mass and strength ${ }^{17}$. The results by SzuLc et al. ${ }^{19}$ also agree with ours, as the authors observed an association between smoking with hormonal fluctuations and sarcopenia risk (sarcopenia was characterized by loss of muscle mass, decrease in strength and increased frailty).

Another factor associated to self-perceived muscular strength loss was the low physical activity score. Some studies have shown a direct association between physical activity and the risk of muscular strength loss $s^{4,18,19}$. On the other hand, many studies have shown that physical activity may bring benefits such as helping to preserve or even increase strength and muscle mass, besides lowering the chance of falls, chronic diseases incidence and aging symptoms ${ }^{6,9,20,21}$. Most of these studies report that physical activity must be performed as weight and strength training to obtain such benefits. However, the present study showed that, regardless of physical activity domain (leisure, commuting, occupation or household chores) and, even among men that did not attain the recommendations for physical activity (as suggested by WHO), even these men perceived less decrease in their strength compared to sedentary men (defined here as no physical activity per week - $0 \mathrm{~min} /$ week of PA).

The self-perceived health was also associated to the perception of decreased strength in our study, those men perceiving their own health as poor were two times more likely to report larger decreases in strength compared to those perceiving their own health as excellent. In a recent study by CoRRÊA et al. ${ }^{9}$, self-perceived health was linearly associated to male's aging symptoms. Other studies have shown that this measure was associated to early death predictors and an elevated risk for chronic diseases in men that considered their health as poor ${ }^{22-24}$. Men that considered their health as good or excellent during the aging process were more active, did not smoke and presented healthier diets, which may resulted in lower loss of muscular strength ${ }^{25}$.

Although the reduction in muscular strength is an irreversible aging process, the extent to which aging negatively affects quality of life can be largely modified by lifestyle characteristics such as quit smoking, regular physical activity. Public health initiatives along with these individual changes in lifestyle could minimize strength reduction and, consequently, to reduce the amount of people affected by this condition associated to aging.

\section{Resumo}

\section{Redução da força em homens em processo de envelhecimento: um estudo de base populacional}

Foi conduzido estudo transversal de base populacional para identificar a prevalência de redução da força em homens em processo de envelhecimento (RFHPE) e os fatores associados à esta condição. Este estudo incluiu 421 homens com idade igual ou superior a 40 anos, residentes na zona urbana da cidade de 
Pelotas, sul do Brasil. Foi utilizado questionário padronizado para coletar informações sociodemográficas, comportamentais e de saúde e, para identificar a redução da força nos homens, utilizou-se uma questão da Escala dos Sintomas do Envelhecimento Masculino. A prevalência de RFHPE foi de 19,0\% (IC $\left.{ }_{95 \%} 15,2-22,8\right)$. Após ajuste para fatores de confusão, a RFHPE foi significativamente associada com idade, fumo, escore de atividade física e autopercepção de saúde. Nossos achados, reforçam a necessidade de manter hábitos saudáveis como não fumar e praticar atividades físicas regularmente. Um estilo de vida saudável, poderá reduzir a aceleração da RFHPE e melhorar a qualidade e a expectativa de vida.

Palavras-Chave: Envelhecimento; Homens; Força; Epidemiologia; População Urbana.

\section{References}

1. Weinert BT, Timiras PS. Physiology of aging: theories of aging. J Appl Physiol. 2003; 95:1706-1716.

2. Mota MP, Figueiredo PA, Duarte JA. Biological theories of aging. Rev Port Cien Desp. 2004;4(1):81-110.

3. Jakiel G, Makara-Studzińska M, Ciebiera M, Słabuszewska-Jóźwiak A. Andropause: state of the art 2015 and review of selected aspects. Prz Menopauzalny. 2015;14(1):1-6.

4. Santilli V, Bernetti A, Mangone M, Paoloni M. Clinical definition of sarcopenia. Clin Cases Miner Bone Metab. 2014;11(3):177-180.

5. Faigenbaum $A D$. Diferenças relacionadas à idade e ao sexo e suas implicaçóes para o exercício de força. In: Beachle TR, Earle RW, editors. Fundamentos do treinamento de força e do condicionamento. Barueri: Manole; 2010. p. 129-145.

6. Delmonico MJ, Harris TB, Visser M, Park SW, Conroy MB, Velasquez-Mieyer P, et al. Health, aging, and body: longitudinal study of muscle strength, quality, and adipose tissue infiltration. Am J Clin Nutr. 2009;90(6):1579-1585.

7. Instituto Brasileiro de Geografia e Estatística. Censo Demográfico. 2000 [cited 2010 Aug 6]. Available from: www.ibge.gov.br.

8. Heinemann LAJ, Zimmermann T, Vermeulen A, Thiel C, Hummel W. A new "aging male's symptoms" (AMS) rating scale. Aging Male. 1999;2(2):105-14.

9. Corrêa LQ, Rombaldi AJ, Da Silva MC, Domingues MR. Aging male's symptoms in a Southern Brazil population: lifestyle effects after the age of 40. Aging Male. 2010;13(2):93-9.

10. Associação Brasileira de Empresas de Pesquisa. Critério de Classificação Econômica Brasil. 2005 June 27 [cited 2008 Sept 10]. Available from: www.abep.org.

11. World Health Organization. Obesity: preventing and managing the global epidemic. Geneva: World Health Organization; 1998.

12. Craig CL, Marshall AL, Sjöström M, Bauman AE, Booth ML, Ainsworth BE, et al. International physical activity questionnaire: 12-country reliability and validity. Med Sci Sports Exerc. 2003;35:1381-1395.

13. Haskell WL, Lee I-M, Pate RR, Powell KE, Blair SN, Franklin BA, et al. Physical activity and public health: updated recommendation for adults from the American College of Sports Medicine and the American Heart Association. Med Sci Sports Exerc. 2007;39(8):1423-1434.

14. T'sjoen G, Goemaere S, De Meyere M, Kaufman JM. Perception of males' aging symptoms, health and well-being in elderly community-dwelling men is not related to circulating androgen levels. Psychoneuroendocrinology. 2004;29(2):201-14.

15. The Andropause Society [cited 2007 June 15]. Available from: http://www.andropause.org.uk/.

16. Carvalho J, Soares JMC. Envelhecimento e força muscular - breve revisão. Rev Port Cien Desp. 2004; 4(3):79-93.

17. Frontera WR, Hughes VA, Fielding RA, Fiatarone MA. Aging of skeletal muscle: a 12-yr longitudinal study. J Appl Physiol. 2000;88:1321-1326.

18. Rom O, Kaisari S, Aizenbud D, Reznick AZ. Cigarette smoke and muscle catabolism in C2 myotubes. Mech Ageing Dev. 2013;134(1-2):24-34.

19. Szulc P, Duboeuf F, Marchand F, Delmas PD. Hormonal and lifestyle determinants of appendicular skeletal muscle mass in men: the MINOS study. Am J Clin Nutr. 2004;80(2):496-503.

20. Marini M, Sarchielli E, Brogi L, Lazzeri R, Salermo R, Sgambati E, et al. Role of adapted physical activity to prevent the adverse effects of the sarcopenia: a pilot study. Ital J Anat Embryol. 2008;113(4):217-225.

21. Churchward-Venne TA, Breen L, Phillips SM. Alterations in human muscle protein metabolism with aging: protein and exercise as countermeasures to offset sarcopenia. Biofactors. 2014;40(2):199-205. 
22. McGee DL, Liao Y, Cao G, Cooper RS. Self-reported health status and mortality in a multiethnic US cohort. Am J Epidemiol. 1999;149:41-46.

23. Chan YY, Teh CH, Lim KK, Lim KH, Yeo PS, Kee CC, et al. Lifestyle, chronic diseases and self-rated health among Malaysian adults: results from the 2011 National Health and Morbidity Survey (NHMS). BMC Public Health. 2015;15:754.

24. Arokiasamy P, Uttamacharya U, Jain K, Biritwum RB, Yawson AE, Wu F, et al. The impact of multimorbidity on adult physical and mental health in low- and middle-income countries: what does the study on global ageing and adult health (SAGE) reveal? BMC Med. 2015;13:178.

25. Huy C, Schneider S, Thiel A. Perceptions of aging and health behavior: determinants of a healthy diet in an older German population. J Nutr Health Aging. 2010;14(5):381-385. 